\title{
THE CHORDOTONAL ORGANS AND PLEURAL DISCS OF CERAMBYCID LARVAE.*
}

\author{
WAt,ter N. Hess.
}

\section{INTRODUCTION.}

For years systematists who have attempted the classification of certain coleopterous larvæ, have been perplexed by the peculiar and varied structures on the abdominal pleural region. These often take the form of a ray-like disc in the larger species, while in the smaller species, a small elliptical enlargement is present in this region. Many larvæ, even among the Coleoptera, do not possess the characters in question, but they seem to be universally present among the Cerambycids. Moreover, they are often much modified in the different genera.

During the summer of 1914 , Dr. W. A. Riley, of this department, found these peculiar pleural structures on various larvæ. About the same time Mr. F. C. Craighead, of the Department of Entomology at Washington, wrote Dr. Riley asking about their functions. It was at this time that the writer undertook a study of their structure.

The writer is sincerely indebted to $\mathrm{Mr}$. Craighead for mounts of these structures which he had turned over to Dr. Riley, also to Dr. Riley himself for much valuable advice and assistance.

In some larvæ, especially the larger species of Prionids, these structures are very pronounced, and instances have been known of students mistaking them for spiracles.

References in the literature are practically limited to a brief mention by Perris (1877). This writer spoke of them in the Cerambycids as "accessory locomotor organs." However, this interpretation was not accepted by Craighead (1915), who refers to them by the non-committal name of "pleural discs:"

It will be shown in this paper that these external characters are not constant in all genera of the Cerambycids, that in spite of an external variation, the internal condition is usually constant, and finally, that the pleural discs are the points of attachment of abdominal chordotonal organs. The detailed structure of the latter will be described.

\footnotetext{
*Contrilution from the Entomological Lahoratory of Cornell University.
} 


\section{MATERIALS AND METHODS.}

Although the histological investigation of this problem was limited to two species, Ergates spiculatus Lec. and Monohammus confusor Kirby, larvæ of other genera were examined to determine the presence and arrangement of the organs. Among these larvæ were specimens of Saperda candida Fabr., Rhagium lineatum Oliv., Desmocerus palliatus Forst., and Mallodon dasystomus Say.

In dissecting out the structure for toto preparations, best results were obtained by opening the larvæ on the mid dorsal line, and pinning them open in a watch crystal which had been half filled with paraffin. As a dissecting medium, picric alcohol was very satisfactory. In addition, Delafield's hæmatoxylin was frequently used to aid in differentiating the tissues for gross dissection. For mounts of the entire organ, staining with borax carmine was very satisfactory. Portions for sectioning were obtained from the fresh larvæ by cutting out the parts in each segment which contained the organs, and placing these directly into fixing fluids.

The parts for histological study were fixed in strong Flemming's solution for twenty-four hours, washed thoroughly, and dehydrated by the usual process. However, formol-chromic acid, as used by Schwabe, was found very satisfactory for fixing these organs. The material was infiltered in $54^{\circ}$ paraffin for three hours, then in $58^{\circ}$ paraffin for one hour, and imbedded. Sections were cut two, three, four, and five microns thick. For the study of cross sections, those cut two and three microns thick were more satisfactory, but for longitudinal sections, those cut at five microns were best, as it was very difficult to obtain thinner sections that showed the internal structures. For staining, Heidenhain's iron hæmatoxylin was found the most satisfactory.

\section{LITERATURE.}

Before taking up the description of these siructures, we shall discuss briefly the more important work that has been done upon the chordotonal organs in insects. It is very probable that more has been written on these structures in the adult Orthoptera than in all the other insects together. Although many authors have described these organs in the insects of other orders, very little attention has been given to their condition in the larvæ. 
According to Graber, details of the auditory organ of insects were first described by John Müller (1826). Müller discovered a structure in the tympanum of the Acrididæ, which he described as an elongated bubble filled with water, one end fastened to the tympanic membrane, the other end extending in the opposite direction.

Siebold (184t) found in the fore tibia of the Locustidæ, a ganglion-like body which ended in the form of a band at the side of a large trachea, and which was composed of rod-shaped little bodies. Some later writers attribute the discovery of the auditory nerve end-organ, or scolopophore, to this worker.

Leydig (1851) found in the larva of Corethra plumicornis, nerve endings which were located in the segments of the abdomen. They were attached at each end to the skin, and stretched lengthwise across the clear space located between the body wall and the muscles. In 1860 Leydig farther investigated the adults and larvæ of Diptera and Coleoptera, and demonstrated the peculiar nerve end apparatus. He described these structures in the antennæ, halteres, and wings, but did no farther work on the abdominal organs. His is the first clear description we find of these nerve end bodies, and as a result Leydig is given credit for discovering them.

Weismann (1866) found in Corethra plumicornis, little nerve endings which he called "cords of hearing." He maintained that this hearing cord was very suitable to be set into vibration by sound waves.

Hensen (1866) showed that in the Locustidæ, the nerve fibers of the auditory nerve join the auditory rod or scolopale. Schmidt (1875) largely confirmed the work of Hensen, but discovered that the nerve fiber extended from a basal ganglion cell into the scolopale.

Although the workers mentioned above contributed considerable to our knowledge of these sense organs, the work of Graber (1881-82) laid the foundation for all future work. This worker called chordotonal, all organs that had.nerve endings similar to those of the previously described auditory rods of the Orthoptera, and maintained that such organs serve an auditory function. He supported this view by showing that chordotonal organs in the various orders of insects all contain peg-like bodies or scolopalæ, such as are found in the tympanal organs of the Orthoptera. 
Graber discovered that chordotonal organs are seldom, if ever, found singly, but usually in groups of two to two hundred or more to a system. He discovered that they are located between two immovable points, usually nea.r the body-wall, free from the movements of the inner organs.

$\mathrm{He}$ found them in various species of Orthoptera, Neuoptera, Hemiptera, Coleoptera, Lepidoptera, Diptera and Hymenoptera. They were not always in the same region of the body, but rather often variously located in the different grouss. He observed them in the segments of the abdomen, in the antennæ of larvæ, in the legs and tarsi, in the halteres, in fore wings and the subcostal veins of hind wings. His extended observations led him to believe that the whole integument of insects, like the tympanum of vertebrates, is especially suited to be set into vibration by sounds, and that the nervous structures united to them can react to different sound waves.

Of the larvæ in which Graber reported finding these structures were: Dytiscus among the Coleoptera; Tabanus, Chironomus, Tanypus, and Syrphus among the Diptera; and Nematus among the Hymenoptera. His descriptions of these larval structures are very suggestive of what I have found in the abdomen of the Cerambycids.

From his rather extensive study of widely separated forms, Graber concluded that these organs, though often different in shape, were all alike in essential details. He noticed that the nerve end-organ had three nuclei, but it remained for a later worker to discover the exact relation between the parts of the structure itself.

Schwabe (1906) in his work on the Locustidæ, first showed that the nerve end-organ or scolopophore is composed of three cells with definite cell boundaries. These are: a cap cell, which is often elongated and attached to the body wall; a central portion or enveloping cell; and the sense cell which bears the nerve.

Schwabe's results have been largely confirmed by Schon (1910), Vogel (1912), and Lehr (1914). 
THE PLEURAL DISCS OF CERAMBYCID LARVA.

We have already seen that the pleural discs of cerambycid larvæ are the outward expression of chordotonal organs. Since these external structures of various larvæ are being used as systematic characters, we will consider briefly their arrangement and relation in the different genera. In many species of the Prionids, such as Mallodon dasystomus, we find a condition such as is shown in Fig. 1, in which there is a pair of definite ray-like structures on the pleural region of each of the first six abdominal segments. These constitute the pleural discs (pl. disc) strictly speaking. On the seventh and eighth abdominal segments they are present, though somewhat modified. Instead of a simple ray-like structure, we find here an elliptical enlargement which Craighead calls the "Pleural tubercle" (P1. Tu.). At the posterio-dorsal side of this tubercle, the pleural disc can be faintly seen (pl. disc). This ray-like structure or pleural disc, has a small median depression, at the central point of which a chitinous cap usually projects for a short distance. From this median depression, there radiate folds in the body wall, producing the previously described ray-like appearance. In addition to these ray-like folds, one often finds at the edge of the disc, folds which run perpendicularly to the rays.

Some of the smaller species of Prionids show the pleural discs only faintly, and then usually best on the first three abdominal segments. However, if one looks carefully, the others may also be found.

Outside of the sub-family Prioninæ, all the species which the writer was able to observe, possessed the elliptical or pleural tubercle. In Saperda candida, Rhagium lineatum, and Desmocerus palliatus, the elliptical enlargements were found on each of the first eight abdominal segments, with a faint evidence of a disc at the posterio-dorsal portion of each tubercle. In many species a slight indication of a disc was also found at the anterioventral end of the tubercle.

In Monohammus confusor a very peculiar condition was observed. The elliptical enlargement or pleural tubercle was present, but instead of a ray-like structure, or pleural disc, at either end there was found a depression in the form of a chit- 
inous invagination, at both the posterio-dorsal and anterioventral ends, as shown in Figs. 2 and 4 (C. Inv.). Instead of opening directly laterally, the pockets open at an angle of about 45 degrees directed away from the pleural tubercle.

THE CHORDOTONAL ORGAN.

On examining the larvæ internally, one finds in the case of the Prionids with the pleural discs, that a peculiar structure in the form of a chordotonal ligament is attached at the central point of the disc, and stretched in an anterio-ventral direction across an irregularly shaped enlargement on the pleural zone, and attached at the other end to a fold in the body wall, as is shown in Fig. 5 (Ch. L.). This ligament is very slender for its posterior two-thirds, but soon thickens towards its anterior third, to two or three times the size of the posterior portion. At about one-half the distance between the beginning of this swelling and the anterior attachment, a branch of the first nerve of the corresponding segment enters the structure from the side. This is the chordotonal nerve (Ch. N.). Anterior to the entrance of the nerve, the structure narrows slightly until. it attaches. In the case of the organs in the seventh and eighth abdominal segments, the condition is slightly different in that the anterior attachment is at the anterio-ventral end of the pleural tubercle, instead of on an anterior body fold as in the other six pairs. This latter condition exists in all eight of the abdominal segments of such species as Saperda candida, Rhagium lineatum, and Desmocerus palliatus. The fact that the ligament attaches anteriorly at the anterio-ventral portion of the pleural tubercle often causes a faint external evidence of a pleural disc in this region.

In Monohammus confusor, the condition is much the same except that at each end of the pleural tubercle, there is a large chitinous invagination (Figs. 2 and 4 , C. Inv.) which projects into the body for a short distance. A chordotonal ligament similar to the one described above, is stretched across the ends of these chitinous structures (Fig. 6, Ch. L.). 


\section{STRUCTURE OF THE NERVE END ORGAN OR SCOLOPOPHORE.}

In the two species, Ergates spiculatus Lec. and Monohammus confusor Kirby, which were studied for their histological structure, there was found a pair of chordotonal ligaments in each of the first eight abdominal segments. Since these organs were alike structurally, a description of one will suffice for both species. Sections were cut of these ligaments in the different abdominal segments of these two species, and also of Mallodon dasystomus Say, and it was found in every case, that each of the eight pairs of cords contained four nerve end organs or scolopophores.

The scolopophores of the cerambycid larvæ correspond in general to those of other orders of insects, and are especially similar to those described by Schwabe (1906). Each is a nerve end organ, composed of a ganglion cell, and two enveloping cells. The ganglion cell or, better, the sense cell, is elongated and covered on its distal end by two enveloping cells, forming a sack-like structure about the distal end of this cell. The distal one of these two enveloping cells serves to unite the end organ with the hypodermis, and is called the cap cell. (Figs. 7 and 8 , C. C.). The other one of the two cells (E. C.) lies between the cap cell and the enlarged portion of the sense cell, while proximad to this cell is found the body of the sense cell (S. C.), with its continuation to the nerve (Ch. N.).

The sense cell (Figs. 7, 8 and 9, S. C.), which contains the axis fiber (Fig. 9, A. F.), is of the bipolar nerve type, continuous proximad with the chordotonal nerve (Ch. N.). Its distal portion penetrates the center of the enveloping cell into the proximal end of the cap cell, where the nerve enlarges to form the peg-shaped body or scolopale (Sc.). The cell enlarges in its middle portion, in which region is found a large spherical shaped nucleus, containing large and fine chromatin parts. The cytoplasmic structure is similar to that of other nerve tissues. An axis fiber runs nearly straight through the sense cell, except where it bends around the large nucleus. As it enters the proximal end of the cell, it is very small, but as it approaches the distal end, it gradually becomes much enlarged. However, at the point where it enters the peg-shaped body, or scolopale, 
it again becomes very small, and continues as a fine cord until it joins a knob-shaped structure near the apex (the end knob Fig. 9, E. K.).

In the larvæ under consideration, these peg-shaped bodies, or scolopalæ, were found located near together with their distal ends in the region where the thickened portion of the chordotonal ligament begins to taper posteriorly. In this rather narrow region is located the distal end of the posterior of the four scolopalæ, and the other three are arranged in a series anteriorly, so that no two of the four organs are the same distance from the posterior end. These scolopalæ are considered by most authors as the enlarged terminal portions of the axis fibers. However, Schwabe is not of this opinion but considers each as a cap-like enveloping apparatus itself. With this latter interpretation m.y results do not accord.

In general, the scolopalæ in Ergates spiculatus are very much like the ones which Schwabe described for the Orthoptera. At the base of each is a vacuole (Fig. 9, V.) which connects with the hollow central portion and, according to Schwabe, is filled with a watery fluid. The number of outer strands or ribs (Fig. 10 B., R.) of which the scolopale is composed, is different from what Schwabe found, in that there are seven large basal strands which divide a little over one-third their distance distally, making a total of fourteen (Fig. 10 C., R.). The dark cap, or $\mathrm{knob}$, located in the distal portion of the scolopale was found to be composed of seven large, opaque divisions, corresponding to the seven basal parts. (Fig. 10 D.; E. K.). However, the exact relation between these and the fourteen ribs could not be determined, though it seems very probable that the ribs pass along the exterior portion of the knob, and form the terminal ligament (Fig. 10 A., T. L.), which extends into the cap cell for about one-fourth the length of this cell. The entire scolopale, except possibly the terminal ligament, is bathed in the watery liquid, and is free to vibrate.

The enveloping cell is a rather large, elongated cell, which lies like a funnel over the greater part of the distal end of the sense cell (Fig. 9, E. C.). It is composed of a light, nearly transparent, alveolar, cytoplasmic structure, with an enlarged nucleus (E. C. N.) towards its proximal end. 
The cap cell is located distad of the enveloping cell, and connects it with the body wall (Figs. 7 and 8, C. C.). It contains at its base the distal end of the sense cell, with its scolopale. Structurally, the protoplasm of this cell is of a much denser nature than that of either of the other two cells, but about its proximal portion the protoplasm is not as dense as farther distad. The whole cell is more or less filled with dark staining strands, or fibrils (F.), which pass in a rather winding condition, somewhat as the strands of a rope, to the distal end, where they unite directly to the cuticula (C. C. A.). This cell is exceptionally long and spindle-shaped and, as Weismann suggested, it seems very capable of vibrating. Near its proximal end is a small elliptical nucleus (C. C. N.), containing dark areas of chromatin.

The portion of the chordotonal ligament anterior to the enveloping cells, and at the sides of the sense cells, is composed of a substance which Schwabe called the "fibrillar binding substance." (Figs. 7, and 8, B. S.). This structure begins to appear in the region of the proximal part of the enveloping cells, and continues along the sides of the sense cells to the anterior attachment. It contains many nuclei, but in no case were cell boundaries seen. These fibrillar strands with their nuclei finally occupy the entire cord at its anterior portion, and by means of these fibrils the cord is fastened directly to the cuticula, much in the same way as at the posterior end. Schwabe regards this fibrillar binding substance as a continuation of the covering of the nerve. This idea seems quite plausible from the appearance of this substance about the sense cells. However, when one considers the character of the fibrils, the nuclei, and the method of attachment, it may be interpreted as a separate modified hypodermal structure.

All larvie that were studied possessed eight pairs of these abdominal organs. The ones at the anterior part of the abdomen were one-fourth to one-half a millimeter longer than those in the posterior segments, while the others formed a proportional gradation in between.

Since the four nerve endings of each cord are so arranged that no two are the same distance from the posterior attachment, it seems very evident that there is a possibility that the larva is able to detect sounds of different wave lengths. 
Authors disagree regarding the function of these organs. Graber ('82), Schwabe ('06), Schon ('10), and many others regard them as organs of hearing, but some of the more recent writers, such as Radl ('05) maintain that they have a static function.

No muscles were found which appeared to function in regulating the length of the ligaments, and it seems, so far as could be discerned, that the length is constant. In the Corethra larva these ligaments have been observed to shorten and lengthen in the living animal, but from a study of the chordotonal ligaments in the wood-boring Cerambycid larvæ, it does not seem possible that their length is changeable.

The external covering of the chordotonal ligament is rather thick, due largely to the fact that the basement.membrane which covers the hypodermis internally, also forms a covering about this structure.

What relation the tracheal system has to these organs is not certain. Schwabe ('06) found enlarged tracheal sacks in the region of the organs in the Orthoptera. Vogel ('12) found a corresponding relation between the chordotonal organs in the wings of butterflies and the trachea. Lehr ('14) found a similar condition in the wings of Dystiscus marginalis. In the abdomen of the forms here studied, a rather large trachea was always observed in close apposition to that part of the chordotoral ligaments which contained the peg-shaped bodies or scolopalæ.

The cuticula at the posterior point of attachment of the chordotonal ligaments in all species studied, and at both ends in Monohammus confusor, was found modified into a very hard, dark-staining structure. This condition, together with the arrangement of the scolopalæ in the ligaments, seems to favor the idea that the organs are for hearing, rather than for balancing, since sound waves could easily be transferred by this hardened cuticula to the ligament, which by its vibration, could carry the impulse to the nerve and organ. 


\section{BIBLIOGRAPHY.}

Berlese, A. 1909. (Sli insetti; loro organizzazione, sviluppo, abitudini e rapporti coll 'uomo. Milano. pp. 633-646.

Craighead, F. C. 1915. Larvæ of the Prioninæ. Washington, D. C., U. S. Agric. Dept.. Rept. 107. 24 pp., pl. 8.

Graber, V. 1881. Uber die stifteführenden und chordotonalen Sinnesorgane bei den insecten. Zool. Anz. IV:450-453.

-1882-3. Die chordotonalen Sinnesorgane und das Gehör der Insecten. Arch. fur Mikr. Anat. XX:506-643, 6 Taf. XXI:65-145.

Hensen, V. 1866. Uber das Gehörorgan von Locusta. Zeit. für wiss. Zool. XVI:190-207. 1 Taf.

Lehr, R. 1914. Die Sinnesorgane der beiden Flügelpaare von Dytiscus marginalis. Zeit. für wiss. Zool. CX : 87-150.

Leydig, F. 1851. Anatomisches und Histologisches über die Larve von Corethra plumicornis. Zeit. für wiss. Zool. III : 435-451. 1 Taf.

- 1860. Utber Geruchs-und Gehörorgane der Krebse und Insekten. Müllers Arch. fur Anat. Phys. und wiss. Med. pp. 265-314. 3 Taf.

Muller, J. 1826. Zur vergleichenden Physiologie des Gesichtssinnes des Menschen und der Thiere. Leipzig. pp. 437-462.

Packard, A. S. 1898. A text book of Entomology. New York, pp. 287-293.

Perris, M. E. 1877. Larves des Coléoptères. Paris, p. 419.

Pflugsteadt, H. 1912. Die Halteren der Dipteren. Zeit. für wiss. Zool. C:1-59. 4 Taf.

Radl, E. 1905. Uber das Gehör der Insekten. Biol. Centralbl. XXV : 1-5.

Schmidt, O. 1875. I) ie Gehörorgane der Heuschrecken. Arch. für Mikr. Anat. $\mathrm{XI}: 19 \mathrm{j}-215.3$ Taf.

Schon, A. 1911. Bau und Entwicklung des tibialen Chordotonalorgans bei der Honigbiene und bei Ameisen. Zool. Jahrb. XXXI : 439-472. 3 Taf.

Schroeder, C. 1912. Handbuch der Entomologie. Jena. I : 160-177.

Schwabe, J. 1906. Beiträge zur Morphologie und Histologie der tympanalen Sinnesapparate der (Orthopteren. Zoologica. XX : 1-154. 5 Taf.

von Siebold, C. T. 1844. Uher das Stimm-und Gehörorgane der Orthopteren. Weigmanns Arch. für Naturg. X : 52-81. 1 Taf.

Vogel, R. 1912, Uber die Chordotonalorgane in der Wurzel der Schmetterlungsflügel. Zèit. für wiss. Zool. C : 210-244. 2 Taf.

Weismann, A. 1866. I) Metamorphose der Corethra plumicornis. Zeit. für wiss. Zexol. XVI : 4j-127. 5 Taf. 


\section{EXPLANATION OF PLATES. \\ Plate IV.}

Fig. 1. Lateral view of the larva of Mallodon dasystomus Say. Amb Amp, Ambulatory ampulla; Hy $\mathrm{P}$, hypopleurum; in seg, intersegmental area; $\mathrm{pl}$ disc. pleural disc; P1 Tu, pleural tubercle; Pl Z, pleural zone; Pnot, pronotum; P. Scl, postscutellum; S, spiracle; Sp A, spiracular area.

Fig. 2. Lateral view of the larva of Monohammus confusor Kirby. Amb Amp, Ambulatory ampulla; $C$ Inv, chitinous invagination; $\mathrm{Hy} \mathrm{P}$, hypopleurum; P1 Tu, pleural tubercle; Pnot, pronotum; S, spiracle.

Fig. 3. Enlarged pleural disc of the first abdominal segment of Mallodon dasystomus Say. C Pl, center of pleural disc, with ch:tinous cap; R Pl, ridge of pleural disc.

Fig. 4. Pleural tubercle of the sixth abdominal segment of Monohammus confusor Kirby. C Inv, chitinous invagination; P1 Tu, pleural tubercle; Se, seta.

\section{Plate V.}

Fig. 5. Left side of the third abdominal segment of Ergates spiculatus opened from the dorsal side. A A , anterior attachment of chordotonal ligament; $\mathrm{Ch} \mathrm{L}$, chordotonal ligament; $\mathrm{Ch} \mathrm{N}$, chordotonal nerve; $\mathrm{G} \mathrm{Cn}$, ga:nglion of central nervous system; Hy $\mathrm{P}$, hypopleurum; in seg, intersegmental area; $\mathrm{N}$, nerve; $\mathrm{P} A$, posterior attachment of chordotonal ligament; P1 Z, pleural zone; S, spiracle.

Fig. 6. Left side of the sixth abdominal segment of Monohammus confusor Kirby, opened from the dorsal side. A A, anterior attachment of chordotonal ligament; $\mathrm{Ch} \mathrm{L}$, chordotonal ligament; $\mathrm{Ch} \mathrm{N}$, chordotonal nerve; $\mathrm{C}$ Inv, chitinous invagination; $\mathrm{G} \mathrm{Cn}$, ganglion of central nervous system; Hy $\mathrm{P}$, hypopleurum; in seg, intersegmental area; $\mathrm{N}$, nerve; $\mathrm{P} A$, posterior attachment of chordotonal ligament; P1 Tu, pleural tubercle; P1 Z, pleural zone; S, spiracle.

\section{Plate VI.}

Fig. 7. Longitudinal vertical section of the pleural tubercle and chordotonal ligament of Monohammus confusor showing two scolopophores. A B S, attachment of binding substance, at anterior end; B S, binding substance; B S N, binding substance nucleus; C C, cap cell; C C A, cap sell attachment, at anterior end; $\mathrm{C} \mathrm{C} \mathrm{N}$, cap cell nucleus; $\mathrm{Ch} \mathrm{N}$, chordotonal nerve; $C$ Inv, chitinous invagination; $\mathrm{E} \mathrm{C}$, enveloping cell; $\mathrm{E} \mathrm{C} \mathrm{N}$, enveloping cell nucleus; $\mathrm{E} \mathrm{K}$, end knob; F, fibrils of cap cell; $\mathrm{H}$ yp, hypodermis; M C, modified cuticula; P C, primary cuticula; $S C_{1}$, secondary cuticula; S C, sense cell; Sc, scolopale; S. C. N, sense cell nucleus; $T \mathrm{~L}$, terminal ligament; $\mathrm{V}$, vacuole.

Fig. 8. Longitudinal vertical section of the pleural zone and chordotonal ligament of Ergates spiculatus showing two scolopophores; A B S, attachment of binding substance, at anterior end; $B S$, binding substance; $B S N$, binding substance nucleus; $\mathrm{C} \mathrm{C}$, cap cell; $\mathrm{C}$, chitinous cap; $\mathrm{C} \mathrm{C} \mathrm{N}$, cap cell nucleus; $\mathrm{Ch} \mathrm{N}$, chordotonal nerve; $\mathrm{E} \mathrm{C}$, enveloping cell; $\mathrm{E} \mathrm{C} \mathrm{N}$, enveloping cell nucleus; $\mathrm{E} \mathrm{K}$, end knob; F, fibrils of cap cell; Hyp. hypodermis; M C, modified cuticula; P C, primary cuticula; S $\mathrm{C}_{1}$, secondary cuticula; S C, sense cell; Sc, scolopale; S C N, sense cell nucleus; $T \mathrm{~L}$, terminal ligament; $\mathrm{V}$, vacuole.

\section{Plate VII.}

Fig. 9. Enlarged portion of scolopophore. A F, axis fiber; C C, cap cell; C C N, cap cell nucleus; $\mathrm{E} \mathrm{C}$, enveloping cell; $\mathrm{E} \mathrm{C} \mathrm{N}$, enveloping cell nucleus; $\mathrm{E} \mathrm{K}$, end knob; F, fibrils of cap cell; Sc, scolopale; S C, sense cell; S C N, sense cell nucleus; T L, terminal ligament; V, vacuole.

Fig. 10. $A$ is an enlarged peg shaped body or scolopale with portions of the three cells of the scolopophore. $B$ is a cross-section in the region of the proximal portion of the scolopale. $C$ is a cross section in the region of the center of the scolopale. $D$ is a cross-section in the region of the end knob. A F, axis fiber; C C, cap cell; D S C, distal portion of sense cell; $\mathrm{E} \mathrm{C}$, enveloping cell; $\mathrm{E} \mathrm{K}$, end knob; $\mathrm{F}$; fibrils of cap cell; Sc, scolopale; R, rib of scolopale; T L, terminal ligament; V, vacuole. 
1.

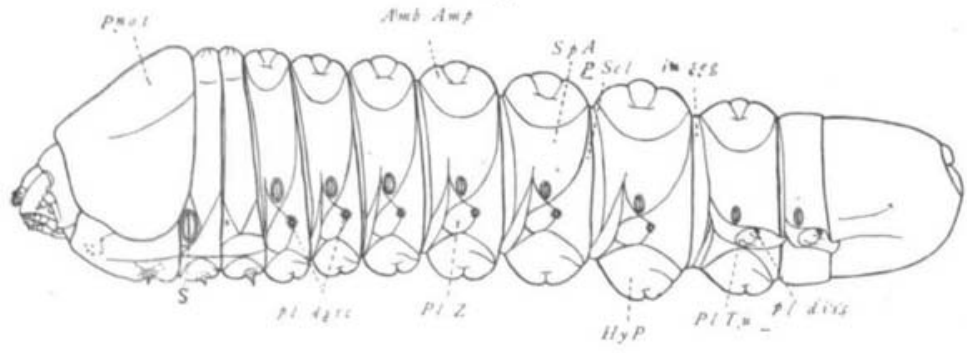

$\longmapsto 10 \mathrm{~mm} \longrightarrow$

2.

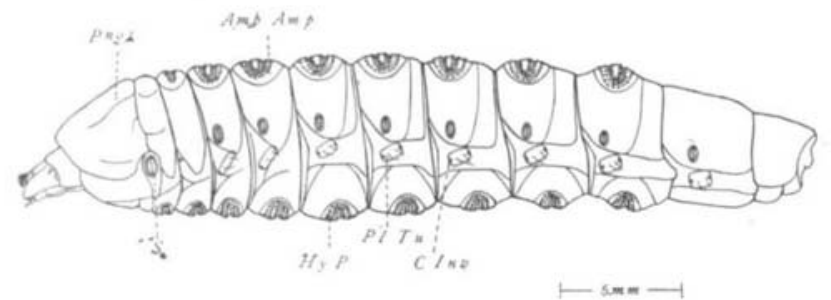

3.

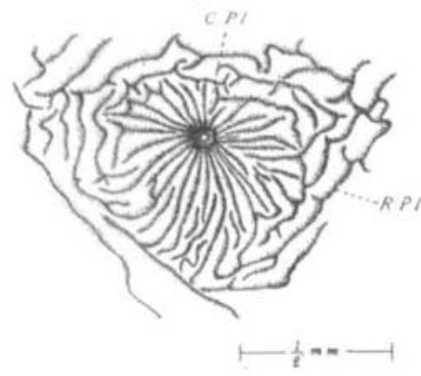

4.

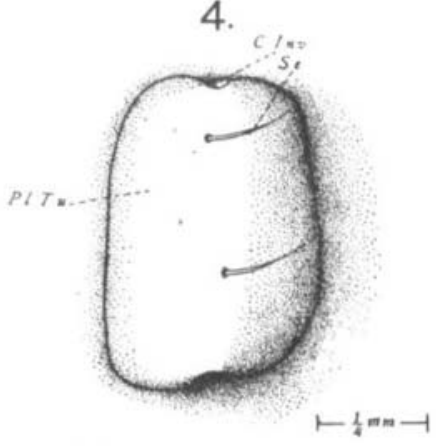

W. N. Hess. 

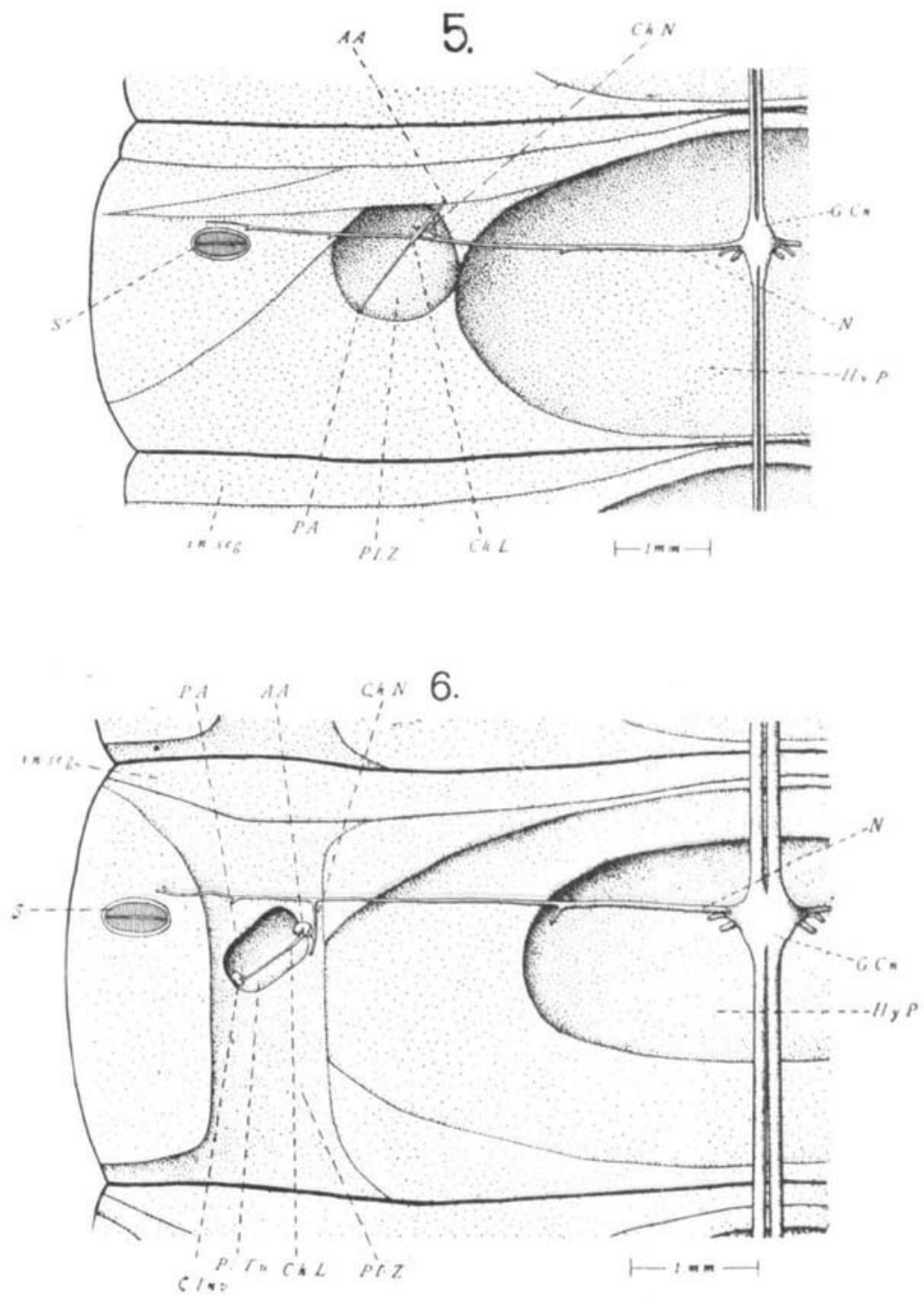

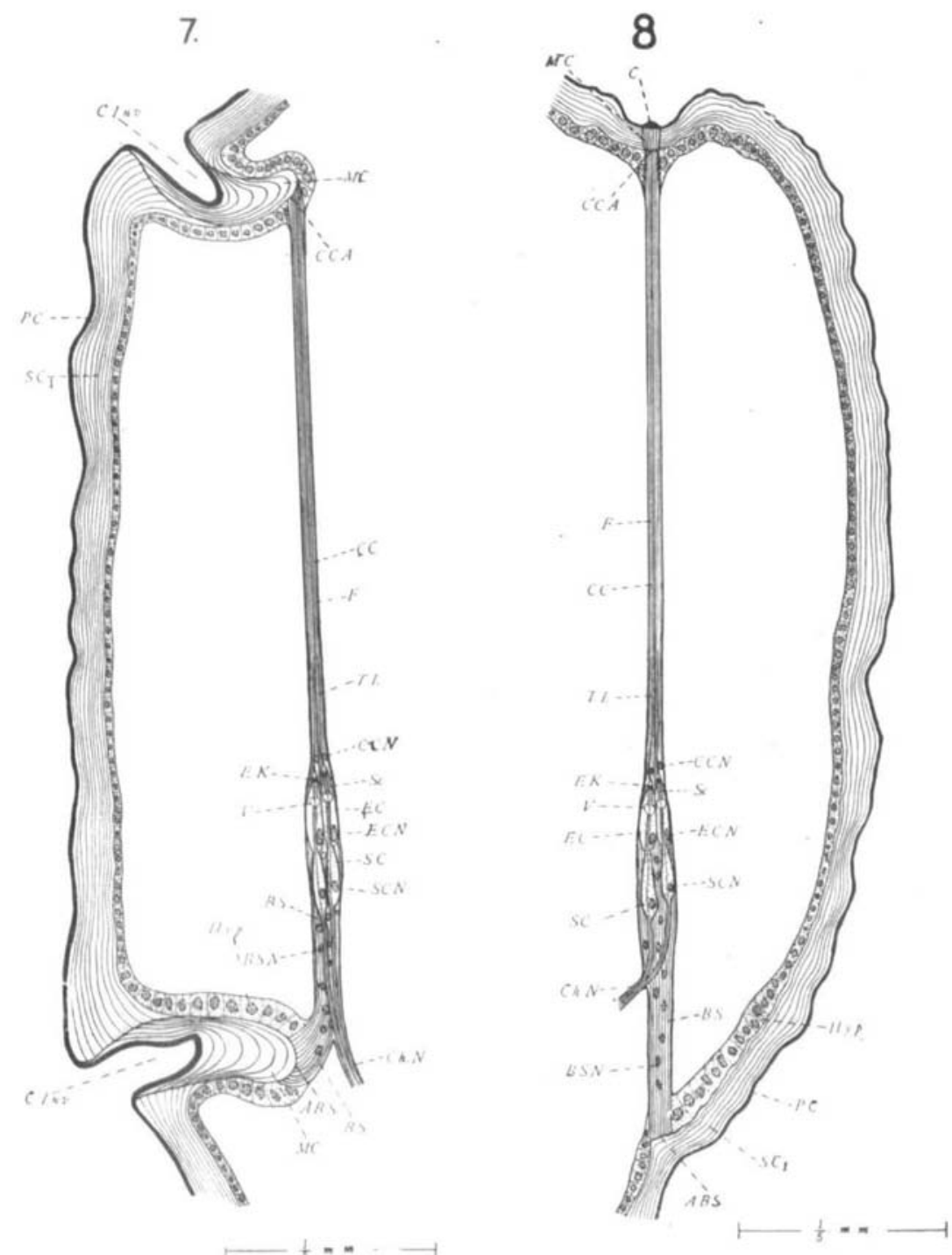

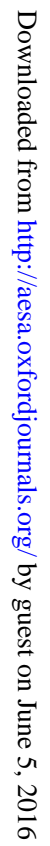

II. N. Hess. 
9.

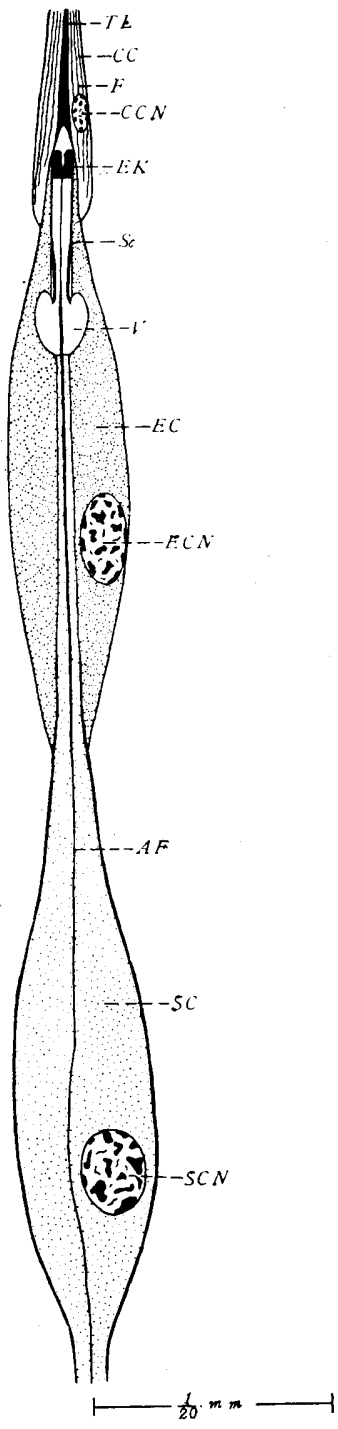

10.

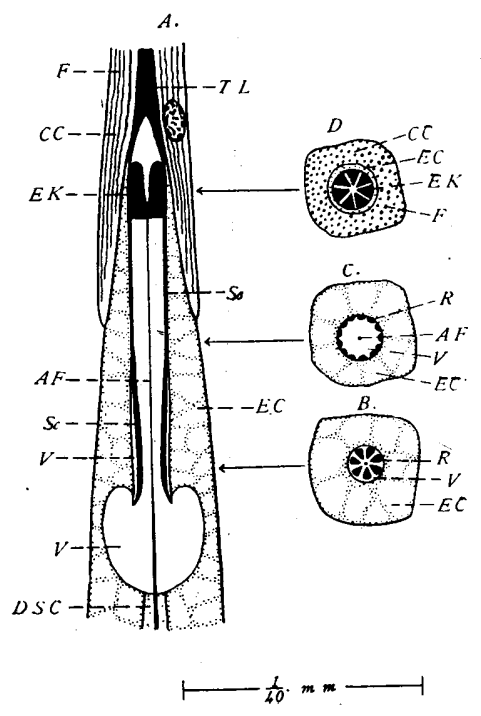

